\title{
Effect of Sediment Manipulation on the Biogeochemistry of Experimental Sediment Systems
}

\author{
Elka T. Porter ${ }^{*}$, Michael S. Owens ${ }^{\ddagger}$, and Jeffrey C. Cornwell ${ }^{*}$ \\ Chesapeake Biological \\ Laboratory \\ University of Maryland \\ Center for Environmental \\ Science \\ P.O. Box 38 \\ *Horn Point Laboratory \\ University of Maryland \\ Center for Environmental \\ Science \\ P.O. Box 775 \\ Cambridge, MD 21613, U.S.A.
}

1 Williams Street

Solomons, MD 20688, U.S.A.

porter@american.edu

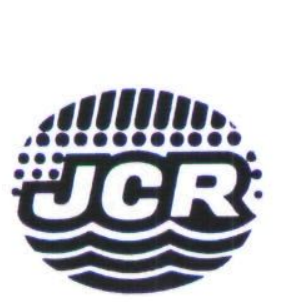

\begin{abstract}
PORTER, E.T.; OWENS, M.S., and CORNWELL, J.C., 2006. Effect of sediment manipulation on the biogeochemistry of experimental sediment systems. Journal of Coastal Research, 22(6), 1539-1551. West Palm Beach (Florida), ISSN 0749-0208.

Before biological or biogeochemical experimentation, sediments are often manipulated and defaunated with the use of many different approaches and only modest consideration of treatment effects on sediment biogeochemistry and fluxes. Mesocosm experiments require large quantities of sediment and no standard protocol to defaunate and equilibrate muddy sediments before initiation of experiments has been determined.

Using fine-grained sediments, we examined a number of treatments: (1) intact with macroinfauna; (2) intact, macroinfauna individually removed; (3) homogenized surface sediment with macrofauna; (4) homogenized deep sediment without macroinfauna; and (5) intact deep sediment without macroinfauna. In weekly batch core flux incubations, we measured dissolved oxygen, dinitrogen gas, ammonium $\left(\mathrm{NH}_{4}^{-}\right)$, nitrate plus nitrite $\left(\mathrm{NO}_{3}^{-}+\mathrm{NO}_{2}^{-}\right)$, silicate $(\mathrm{Si})$, and soluble reactive phosphorus (SRP) fluxes over a 5-week period. In addition, we determined porewater ammonium concentrations over time.

Different sediment preparation techniques, with the same muddy sediment, significantly affected nutrient and gas fluxes, and the amount of nutrient and gas fluxes differed between sediment preparation techniques. Severely manipulated sediments, such as homogenized treatments, had high initial effluxes but eventually equilibrated to lower and more constant nutrient and gas fluxes. Moreover, biogeochemical flux changes for all treatments became similar after about 2 to 3 weeks. Sieved sediments exhibited low fluxes over the entire 5-week period, and flux rates did not change over time. A feasible method for sediment preparation for mesocosm studies is to use homogenized deep sediment equilibrated over an almost 2-week period. Overall, sediment preparation and the time after sediment manipulation affect sediment biogeochemical processes and must be considered before initiating experiments.
\end{abstract}

ADDITIONAL INDEX WORDS: Sediment equilibration, disturbance, defaunation, sediment homogenization, mesocosm, experimental ecosystem, sediment-water exchange.

\section{INTRODUCTION}

Sediments used in micro- or mesocosm studies have been prepared in a variety of ways for use in biogeochemical flux experiments or mesocosm experiments (i.e., Table 1). After collection, sediment has been manipulated for different experimental purposes. Manipulations have included organic matter (CAFFrey et al., 1993; ENOKSSON, 1993; NEWELL, Cornwell, and Owens, 2002; Sloth et al., 1995), addition of organisms (ANDERSEn and KRISTEnsen, 1988; Kim et al., 2004; Pelegrí, Nielsen, and Blackburn, 1994; Porter et al., 2004a), removal of macrofauna (DoERING et al., 1987; Martin and Banta, 1992; Oviatt et al., 1995; SundBack et al., 1991), addition of microphytobenthos (NEwell, CorN-

DOI:10.2112/05-0478.1 received 15 March 2005; accepted in revision 11 November 2005.

* Current address: Biology Department, American University, 4400 Massachusetts Ave, NW, Washington, DC 20016-8007.
WELL, and OWENS, 2002), and addition of both microphytobenthos and macrofauna (Rysgaard et al., 1994). Some experiments have used intact sediments and macrofauna (DoERING, Oviatt, and Kelley, 1986). Natural sediments have been sieved to remove macroinfauna (HANSEN, KING, and Kristensen, 1996; Meyers, Fossing, and Powell, 1987; Pelegrí, Nielsen, and BlackBurn, 1994) and homogenized (KIM et al., 2004; Porter et al., 2004a, 2004b; ZieBis, HuetTEL, and FORSTER, 1996). Another defaunation approach is inducing anoxia in the sediment, followed by upward migration of animals (JøRGENSEN, 1980) and removal at the sediment surface (ANDERSEN and CHRISTENSEN, 1988; HANSEN and BLACKBURN, 1991). Other studies have used intact cores with macrofauna collected with benthic chamber tubes for small-scale studies of in situ conditions (CowAN and BoyNTON, 1996; Giblin, Hopkinson, and TuCKER, 1997; NiELSEN, Nielsen, and RASMussen, 1995) or with box cores for use in mesocosms (Doering, Oviatt, and Kelley, 1986; 


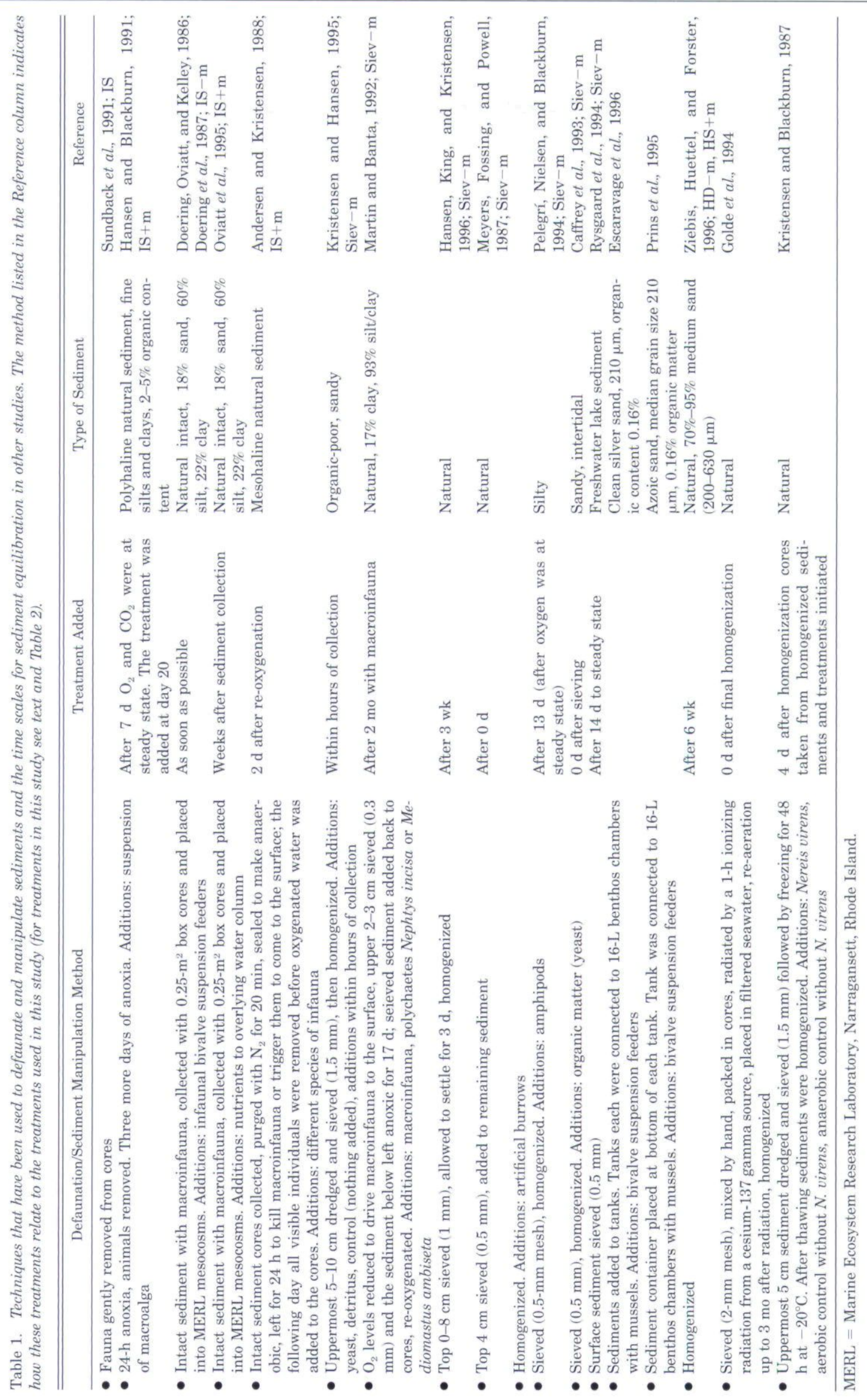


Doering et al., 1987; Oviatt et al., 1995). Alternative defaunation approaches have included deep-freezing (BRUCKNER et al., 1995; KRISTENSEN and BLACKBURN, 1987) or core irradiation (GoLDE et al., 1994). All techniques have consequences for microbial populations. Ammonium concentrations are enhanced and dissolved oxygen concentrations can be reduced in disturbed sediments (MARINELLI and WOODIN, 2002, 2004; Woodin, Marinelli, and Lindsay, 1998). A systematic study to determine the most effective protocol for sediment handling for experimental purposes has not been published.

The time elapsed between sediment manipulations and the start of sediment incubations can vary among experiments and could affect sediment biogeochemistry and subsequent nutrient fluxes. Experiments have been started immediately after the sediment manipulation (DoERING, OviaTt, and Kelley, 1986; Doering et al., 1987; Kristensen and HaNSen, 1995; Meyers, Fossing, and Powell, 1987), 2 months after the addition of macroinfauna (MARTIN and BANTA, 1992), 3 weeks after sediment collection (HANSEN, KING, and KRISTENSEN, 1996), 7-14 d after the addition of organic matter (CAFFrEy et al., 1993), or "weeks after sediment collection" (OviatT et al., 1995). Sometimes the steady state of a variable is used to guide researchers as to when to start the experiment or add the treatment of interest. The time to reach steady state varies widely. For example, observations of the time for oxygen, carbon dioxide, or both to reach steady state ranged from 7 to 13 days (HANSEN and BLACKBURN, 1991; Pelegrí, Nielsen, and BlackBurn, 1994; RysgaArd et al., 1994) with variable times in which manipulations were commenced after apparent steady state.

Experimental studies that use mesocosms require large amounts of sediment, and techniques such as sieving to remove macrofauna to prepare defaunated sediment are logistically difficult. Often the desire is to remove macrofauna in micro- and mesocosm studies because this allows the investigator to attain the experimental fauna and faunal population density of choice (ANDERsEn and Kristensen, 1988; Kim et al., 2004; Pelegrí, Nielsen, and Blackburn, 1994; Pietros and Rice, 2003; Porter et al., 2004a). Martin and BANTA (1992) used sieved over unsieved sediment to maintain sediment structure. Alternatively, some mesocosm studies with sediment have used azoic sand (PRINS et al., 1995), mixtures of sand and silt (Petersen, Chen, and Kemp, 1997; Petersen, Sanford, and Kemp, 1998), or box cores with intact sediment and organisms (DOERING, OviatT, and Kelley, 1986; Doering et al., 1987; Oviatt et al., 1995).

This study examines the effect of sediment manipulation and defaunation on nutrient and gas flux rates over time for muddy sediments. Although some aspects of sediment preparation have been addressed in previous studies (BRUCKNER et al., 1995; FleTCHER, REYNOLDSON, and TAYLOR, 2001), we pose three questions: (1) Are biogeochemically disturbed or defaunated sediments able to equilibrate to similar and relatively constant nutrient and gas flux rates over time? (2) If so, how much time elapses before disturbed sediments equilibrate to constant gas and nutrient flux rates? (3) What is a feasible large-scale sediment defaunation technique for mesocosm studies and studies with sediment cores?

\section{METHODS}

\section{Sediment Treatments}

Sediments were collected from a shallow water of the mesohaline Choptank River (Chesapeake Bay) by hand-coring with 12.7-cm-diameter acrylic chambers. Grain sizes of two cores in the vicinity of our sediment collection site were $20 \%$ sand, $21 \%$ silt, $59 \%$ clay (CoRNWELL, unpublished data). Macrofauna was abundant at our site, and two cores at about $10 \mathrm{~cm}$ sediment depth were collected to determine macrofauna abundance. One 12.7-cm-diameter sediment core, rendered anaerobic by sealing the core, and animals individually picked, contained two polychaetes, 46 amphipods, and one unidentified crustacean. A second 12.7-cm-diameter core with $\sim 10 \mathrm{~cm}$ of sediment and an overlying water column of $26 \mathrm{~cm}$ contained 13 polychaetes, 52 amphipods, one snail, and two bivalves. Sediments were manipulated in six different ways (Table 2); some treatments were defaunated $(-\mathrm{m}$, minus macrofauna) by sealing the core, sieving, or covering the sediment with plastic, and others were not $(+\mathrm{m}$, plus macrofauna; Table 2). We chose sediment preparation techniques (e.g., $\mathrm{IS}-\mathrm{m}, \mathrm{IS}+\mathrm{m}, \mathrm{HS}+\mathrm{m}, \mathrm{HD}-\mathrm{m}$, Siev $-\mathrm{m}$; Table 2) that commonly have been employed in other studies. The HD $-\mathrm{m}$ treatment was included as a feasible option for large-scale sediment preparation for mesocosm studies. The ID-m treatment was chosen to represent dredged sediment.

The IS $-\mathrm{m}$ cores were driven to anoxia, and macrofauna were picked from the sediment surface daily until no fauna was observed after a 4 -d period. The top 10 -cm section of cores, with macrofauna, was used for the IS $+\mathrm{m}$ treatment, and the section below $10 \mathrm{~cm}$ depth was used for the ID $-\mathrm{m}$ sediment treatment. The HS $+m$ treatment consisted of homogenized sediment from the top $10 \mathrm{~cm}$ of cores and included macrofauna.

The sediment sections below $10 \mathrm{~cm}$ were placed into another bucket, thoroughly mixed, placed into core tubes, and smoothed to form the $\mathrm{HD}-\mathrm{m}$ sediment treatment; no macroinfauna were below $10 \mathrm{~cm}$ depth. For the Siev-m sediment treatment, sediment was sieved through a $0.5-\mathrm{mm}$ mesh to remove macroinfauna, and sediment was placed into core tubes with a depth sufficient to compensate for sediment compaction and provide about $10 \mathrm{~cm}$ sediment height.

Failure of the aeration system lead to a lack of oxygenation of the initial $\mathrm{HS}+\mathrm{m}$ treatment after 2 weeks, and the HS was remixed. This treatment was reinitiated at that point (labeled $\mathrm{HS}+\mathrm{m}^{\mathrm{a}}$ ). The flux experiments were run with the other cores or, in one case, run as the only cores with control cores. An offset correction in time was applied to the $\mathrm{HS}+\mathrm{m}^{\circ}$ cores.

\section{Setup of Cores}

Our incubation system consisted of 12.7-cm-diameter acrylic cores, with a $10-\mathrm{cm}$ sediment depth and a $26-\mathrm{cm}$ overlying water column (total water volume was $3300 \mathrm{ml}$ ). Cores for the anaerobic treatments (IS $-\mathrm{m}, \mathrm{HD}-\mathrm{m}$ ) were collected 6 days before the first flux experiment and left at room temperature under anaerobic conditions until the start of re-aeration. Organisms were removed daily from IS $-\mathrm{m}$. Cores for 
Table 2. Sediment preparation for treatments used in this study.

\begin{tabular}{|c|c|c|}
\hline Treatment ID & Treatment & Preparation Procedures for Sediment Treatments \\
\hline $\mathrm{IS}-\mathrm{m}$ & $\begin{array}{l}\text { Intact surface sediment, macro- } \\
\text { fauna individually removed }\end{array}$ & $\begin{array}{l}\text { Intact surface sediment was driven anoxic to trigger macroinfauna to come to the surface. Ma- } \\
\text { croinfauna that appeared at the sediment surface because of increasingly anaerobic conditions } \\
\text { was removed daily without disturbing the sediments. This was repeated until all macroinfauna } \\
\text { was individually removed from the cores, which took } 5 \mathrm{~d} \text {. Core incubations were started after } \\
\text { removal of all macroinfauna (i.e., week } 0 \text { ). }\end{array}$ \\
\hline $\mathrm{HD}-\mathrm{m}$ & $\begin{array}{l}\text { Homogenized deep, no macro- } \\
\text { fauna }\end{array}$ & $\begin{array}{l}\text { Homogenized deep sediment sections from }>10 \mathrm{~cm} \text { depth without macroinfauna. Dredged natural } \\
\text { sediment was collected into a tank with as little overlying water as possible. The sediment was } \\
\text { homogenized, driven anoxic by adding black tarp over the surface after water removal, and then } \\
\text { left in darkness. After } 3 \mathrm{~d} \text {, an } \sim 10 \text {-cm-deep surface layer of sediment was scraped off and dis- } \\
\text { carded to remove any potentially live macroinfauna in this surface section. Cores were then } \\
\text { collected, and the equilibration phase in ambient filtered water was initialized. }\end{array}$ \\
\hline $\mathrm{IS}+\mathrm{m}$ & $\begin{array}{l}\text { Intact sediment with macroin- } \\
\text { fauna }\end{array}$ & Intact cores that included macroinfauna. \\
\hline $\mathrm{HS}+\mathrm{m}, \mathrm{HS}+\mathrm{m}^{\mathrm{a}}$ & $\begin{array}{l}\text { Homogenized surface sediment, } \\
\text { macrofauna }\end{array}$ & $\begin{array}{l}\text { Homogenized surface sediment (top } 10 \mathrm{~cm} \text { depth) that included all macroinfauna. Cores were } \\
\text { restarted after loss of original cores }\left(\mathrm{HS}+\mathrm{m}^{\mathrm{a}}\right) \text {. }\end{array}$ \\
\hline $\mathrm{Siev}-\mathrm{m}$ & $\begin{array}{l}\text { Sieved }(500 \mu \mathrm{m}) \text {, macrofauna re- } \\
\text { moved }\end{array}$ & Sieved sediment (0.5-mm mesh). \\
\hline $\mathrm{ID}-\mathrm{m}$ & $\begin{array}{l}\text { Intact deep sediment section, no } \\
\text { macrofauna }\end{array}$ & A deep sediment section of a core (section between 10 and $20 \mathrm{~cm}$ ). \\
\hline
\end{tabular}

treatment ID-m were collected 2 days before the start of the experiments and re-aerated. Cores for the aerobic treatments $\mathrm{IS}+\mathrm{m}, \mathrm{HS}+\mathrm{m}$, and $\mathrm{Siev}-\mathrm{m}$ were collected 1 day before the start of the initial flux experiments. All sediment cores were transferred to a dark, aerated (by bubbling) water basin filled with $2 \mu \mathrm{m}$ of filtered flow-through estuarine water at 22 $23^{\circ} \mathrm{C}$.

\section{Flux Experiments}

Sediment-water flux experiments were performed in the dark with triplicate cores and bubbled $0.2-\mu \mathrm{m}$ filtered estuarine water that had been exchanged into the cores before incubation. Tubes filled with $0.2-\mu \mathrm{m}$ filtered, aerated replacement water were attached to the lids, the cores were sealed without bubbles and arranged around central magnetic turntables that turned magnetic stirrers in each flux chamber. Stirring rates were below the threshold of sediment resuspension but sufficiently high to ensure a homogeneous water column. During one flux run, filtered water blanks were run in parallel with the sediment incubations to confirm that water column activity was negligible.

Sediment incubations were carried out at the start of the experiment (week 0) and repeated after weeks 1, 2, 3, and 5. Flux incubations for treatment ID-m were carried out in weeks $0,1,2,4$, and 5 . Each incubation was about 18 hours long. During all incubations, oxygen levels were not depleted below half of the starting oxygen concentration so that responses would be linear and macrofaunal stress would be minimal. A minimum of three time points was measured. Dissolved oxygen, $\mathrm{N}_{2}$ gas, and nutrients were sampled. Each sample point removed only $\sim 1.5 \%$ of the core water volume, and no correction for the replacement water addition was required.

During sampling, one $5-\mathrm{ml}$ water sample was collected by gravity flow through valves in the chamber lid into a small glass cylinder for immediate analysis of dissolved oxygen by a Clark-type electrode. The electrode response was checked with Winkler titrations before the experiments. Three 7-ml water samples per core were collected by gravity flow into glass tubes and sealed with a plastic sleeve and a second glass tube (KANA et al., 1998) for $\mathrm{N}_{2}$ : Ar gas ratio analysis to determine $\mathrm{N}_{2}$ gas fluxes. A 25-ml water sample was withdrawn by syringe from the water overlying each core, filtered through a $0.45-\mu \mathrm{m}$ filter, and frozen at $-20^{\circ} \mathrm{C}$ (PARSONS, MAITA, and LALLI, 1984) in 5-ml vials for nutrient $\left(\mathrm{NH}_{4}^{+}\right.$, $\left.\mathrm{NO}_{3}^{-}+\mathrm{NO}_{2}^{-}, \mathrm{SRP}, \mathrm{Si}\right)$ analyses after the experiment.

\section{Time Between Flux Experiments}

Between flux experiments, open sediment cores were aerated by bubbling in the dark in a common flow-through seawater basin held at $22-23^{\circ} \mathrm{C}$. Water was continuously exchanged at a turnover time of once per day with the use of 2 $\mu \mathrm{m}$ of filtered ambient Choptank estuary water at a salinity of 11-12 psu. After the week 1 flux measurements, the oxygen supply was interrupted in the seawater basin affecting treatments with high sediment oxygen demand (treatments $\mathrm{HS}+\mathrm{m}$, IS $+\mathrm{m})$. After the hypoxic event, we discarded all cores from treatment HS $+\mathrm{m}$ (Table 2) used for the weekly flux run and mixed an additional set of three replicate cores for treatment $\mathrm{HS}+\mathrm{m}^{\mathrm{a}}$.

\section{Evaluating Fluxes Over Time}

Three approaches were used to determine the changes in fluxes over time: (1) the results of the fluxes of solutes and gases were visually compared over weekly core incubations over a 5-week period (except week 4); (2) the fluxes of weeks $0,1,2$, and 3 were each compared with week 5 , using week 5 as a benchmark; and (3) the flux changes from week to week were compared statistically. To reduce the volume of data, for (2) and (3), we focused on ammonium and dissolved oxygen because these are biogeochemically and ecologically particularly important; moreover, low fluxes of soluable reactive phosphorus made further analysis trivial. 


\section{Pore Water Extractions}

We prepared 7.6-cm-diameter acrylic cores corresponding to each treatment, held them in the same flow-through water bath as the flux cores, and sectioned them for porewater analyses on weeks 0,2 , and 5 of the experiment. For homogenized treatments $(\mathrm{HD}-\mathrm{m}, \mathrm{HS}+\mathrm{m})$ porewater from one sediment sample from the homogenized mix was used to represent the sediment core at all depths for week 0 . Sediment cores were sectioned under $\mathrm{N}_{2}$ atmosphere in a glove bag to minimize oxidation artifacts. Sediments from 0 to $2 \mathrm{~cm}$ were sectioned in $0.5-\mathrm{cm}$ intervals, with $1-\mathrm{cm}$ intervals from 2 to $4 \mathrm{~cm}$, and sections of $2-\mathrm{cm}$ intervals for sediment below $4 \mathrm{~cm}$ depth. Pore waters were centrifuged at $3600 \mathrm{rpm}$ for 20 minutes, and the supernatant was sieved through a $0.45-\mu \mathrm{m}$ filter and frozen for subsequent porewater ammonium analyses.

\section{Analytical Methods and Analysis}

Ammonium and soluble reactive phosphorus were analyzed colorimetrically (PARsons, MAItA, and LALli, 1984), and both nitrite + nitrate and silicate were determined on a Technicon autoanalyzer (Zimmermann, Price, and MontGOMERY, 1977). Immediately after sampling, the water in the sealed glass tubes was analyzed for $\mathrm{N}_{2}$ : Ar gas ratios with a modified membrane inlet mass spectrometer described in detail in KANA et al. (1994). The $\mathrm{N}_{2}$ gas results were expressed as $\mathrm{N}_{2}-\mathrm{N}$. Rates of $\mathrm{N}_{2}$ gas flux were determined during all flux experiments except in week 0 because of equipment malfunction. Data for $\mathrm{N}_{2}-\mathrm{N}$ flux rates for treatment $\mathrm{HS}+\mathrm{m}$ in week 5 were lost.

\section{Statistical Analyses}

An analysis of variance (ANOVA) was performed for the fluxes of each week after checking the data for normality of the error term with the Shapiro Wilks test and after checking for homogeneity of variance with Levene's test. Data were natural log-transformed as necessary, with ln notations on Figures 1-5 when transformation was necessary. When transformations did not correct for homogeneity and normality, the nonparametric Wilcoxon rank test comparison (WR notation in Figures 1-5) was used. With the use of least squares means tables (SAS lsmeans, SAS Institute, Cary, North Carolina), we compared the significances between treatments within each flux experiment as indicated by letters in Figures 1-5.

In addition, we performed repeated measures analyses of variance (JOHNSON and WICHERN, 1982; SCHEINER and GuREvitch, 1993) on the nutrient and gas flux results from treatments $\mathrm{IS}+\mathrm{m}, \mathrm{HD}-\mathrm{m}$, IS $+\mathrm{m}, \mathrm{HS}+\mathrm{m}$, Siev $-\mathrm{m}$, and ID $-m$ to test whether flux rates were influenced by the type of sediment manipulation and whether differences varied over time. The repeated measures ANOVA is a two-way ANOVA that properly accounts for the dependence over time (JoHNSON and WiCHERN, 1982; SCHEINER and GuREvitCH, 1993). The repeated measures ANOVA included a test for time effects, treatment effects, and a time and treatment interaction. Week 5 was used as a benchmark for stabilization in the nutrient and gas concentrations. For comparison, we included treatment IS $+\mathrm{m}$ in the analysis. Flux measurements on IS $+m$ had been performed on a different core after week 1. In addition, we used repeated measures ANOVA (JoHnson and WiCHERN, 1982; SCHEINER and GUREvitch, 1993) on treatments IS $-\mathrm{m}, \mathrm{HD}-\mathrm{m}, \mathrm{IS}+\mathrm{m}, \mathrm{HS}+\mathrm{m}, \mathrm{Siev}-\mathrm{m}$, and ID $-\mathrm{m}$ to statistically determine whether the nutrient and gas flux rates among the different treatments would become similar between treatments over time. Treatment ID $-\mathrm{m}$ was run in week 4 , instead of in week 3 as noted in the figures and tables, and was excluded from the statistical analyses of week 3 . For HS $+\mathrm{m}$, all statistical analyses were performed on the remixed $\mathrm{HS}+\mathrm{m}^{0}$ cores. To determine the mean difference between week 3 and 5 for each individual treatment, we performed a $t$ test with the null hypothesis that the mean difference was zero between weeks 3 and 5 . All analyses were performed in SAS 8.0 (SAS Institute).

\section{RESULTS}

\section{Porewaters}

Profiles of ammonium concentrations of the homogenized treatments $(\mathrm{HD}-\mathrm{m}, \mathrm{HS}+\mathrm{m}, \mathrm{Siev}-\mathrm{m})$ changed dramatically over time, whereas all other treatments had a sigmoid shape at the onset (Figure 6). High initial ammonium concentrations at the surface of homogenized sediment treatments changed over 2 weeks to sigmoid-shaped profiles with lower ammonium concentrations near the surface and higher concentrations deeper into the core (Figure 6, top). Ammonium profiles at weeks 2 and 5 were similar in shape. Initial porewater ammonium concentrations of the homogenized sediment treatments were highest in $\mathrm{HD}-\mathrm{m}\left(\sim 810 \mu \mathrm{mol} \mathrm{L}{ }^{-1}\right)$, followed by $\mathrm{HS}+\mathrm{m}\left(\sim 450 \mu \mathrm{mol} \mathrm{L}{ }^{-1}\right)$, and lowest in Siev $-\mathrm{m}$ $\left(\sim 180 \mu \mathrm{mol} \mathrm{L}^{-1}\right)$, as shown in Figure 6 (top). The intact deep and intact surface sediment had high ammonium concentrations at the surface (Figure 6, bottom). High initial ammonium porewater concentrations near the surface of the homogenized deep and the homogenized surface sediment resulted in high initial ammonium effluxes (Figure 1). Initially, the intact deep and intact surface sediment also had high ammonium concentrations at the sediment surface (Figure 6, bottom).

\section{Fluxes}

\section{Fluxes of Solutes and Gases over a 5-week Period}

Soluble reactive phosphorus fluxes were not detectable throughout these experiments; however, the nitrogen and gases were dynamic over time. In week 0 , ammonium effluxes were close to zero in treatments $\mathrm{Siev}-\mathrm{m}$ and ID $-\mathrm{m} ; \sim 400$ $\mathrm{mol} \mathrm{m}^{-2} \mathrm{~h}^{-1}$ in treatments $\mathrm{IS}-\mathrm{m}, \mathrm{HD}-\mathrm{m}, \mathrm{IS}+\mathrm{m}$, and $\mathrm{HS}+\mathrm{m}^{\mathrm{a}}$; and $\sim 700 \mu \mathrm{mol} \mathrm{m}{ }^{-2} \mathrm{~h}^{-1}$ in treatment $\mathrm{HS}+\mathrm{m}$ (Figure 1). The pattern of ammonium efflux rates in week 1 were similar to week 0, with somewhat lower rates. Ammonium fluxes decreased over time and differences between treatments also decreased over time (Figure 1). ANOVA and least squares mean comparisons indicated significant differences between the treatments.

Oxygen uptake rates were $\sim 1500 \mu \mathrm{mol} \mathrm{m}^{-2} \mathrm{~h}^{-1}$ at the start of the experiment (week 0 ), except for treatments IS $+\mathrm{m}$ and 


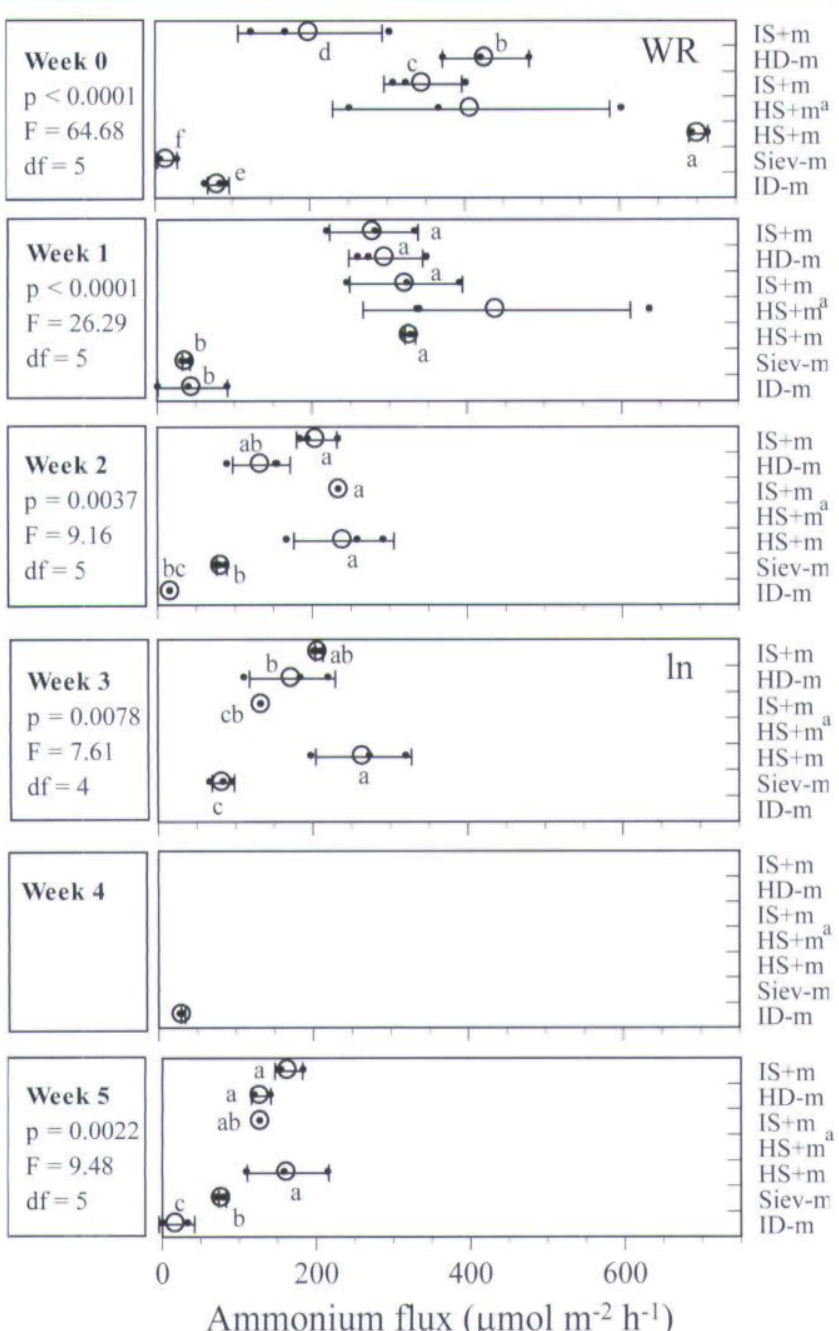

Figure 1. Ammonium fluxes measured approximately weekly over a 5wk period. The large open circle represents the mean flux rate and the bar the standard deviation. The small closed circles represent the flux rate of the individual cores that constitute the mean flux rate and contribute to the standard deviation from the mean. Results of an ANOVA run for each week are reported on the left of each panel. WR = data analyzed with the Wilcoxon Rank test, $\mathrm{Ln}=\log$-transformed data. Probability is indicated as ns $=$ nonsignificant $(p>0.05)$ and significant $(p$ $<0.05, p<0.01$, and $p<0.001$ ). For sediment preparation treatments, see Table 2 .

$\mathrm{HS}+\mathrm{m}^{\mathrm{a}}$ (Figure 2) with rates of 4500 and $3000 \mu \mathrm{mol} \mathrm{m}^{-2} \mathrm{~h}^{-1}$, respectively. Differences among treatments decreased over time but were still significant at the end of the experiment (Figure 2). ANOVA and least squares mean comparisons indicated significant differences between the treatments.

In week 0 , nitrate + nitrite uptake rates of $\sim 150 \mu \mathrm{mol} \mathrm{m}^{-2}$ $\mathrm{h}^{-1}$ were observed for sediment treatments $\mathrm{IS}+\mathrm{m}$ and $\mathrm{HS}+\mathrm{m}^{\mathrm{a}}$, with nitrate + nitrite effluxes of about $100 \mu \mathrm{mol}$ $\mathrm{m}^{-2} \mathrm{~h}^{-1}$ for treatments IS $+\mathrm{m}$ and $\mathrm{HD}-\mathrm{m}$ (Figure 3 ). Nitrite + nitrate fluxes in treatments $\mathrm{Siev}-\mathrm{m}$ and $\mathrm{ID}-\mathrm{m}$ were close to zero. The flux data for $\mathrm{HS}+\mathrm{m}$ and $\mathrm{IS}+\mathrm{m}$ were variable in week 0 but became less variable with time. All nitrate + nitrite fluxes were about zero by the end of the experiment.

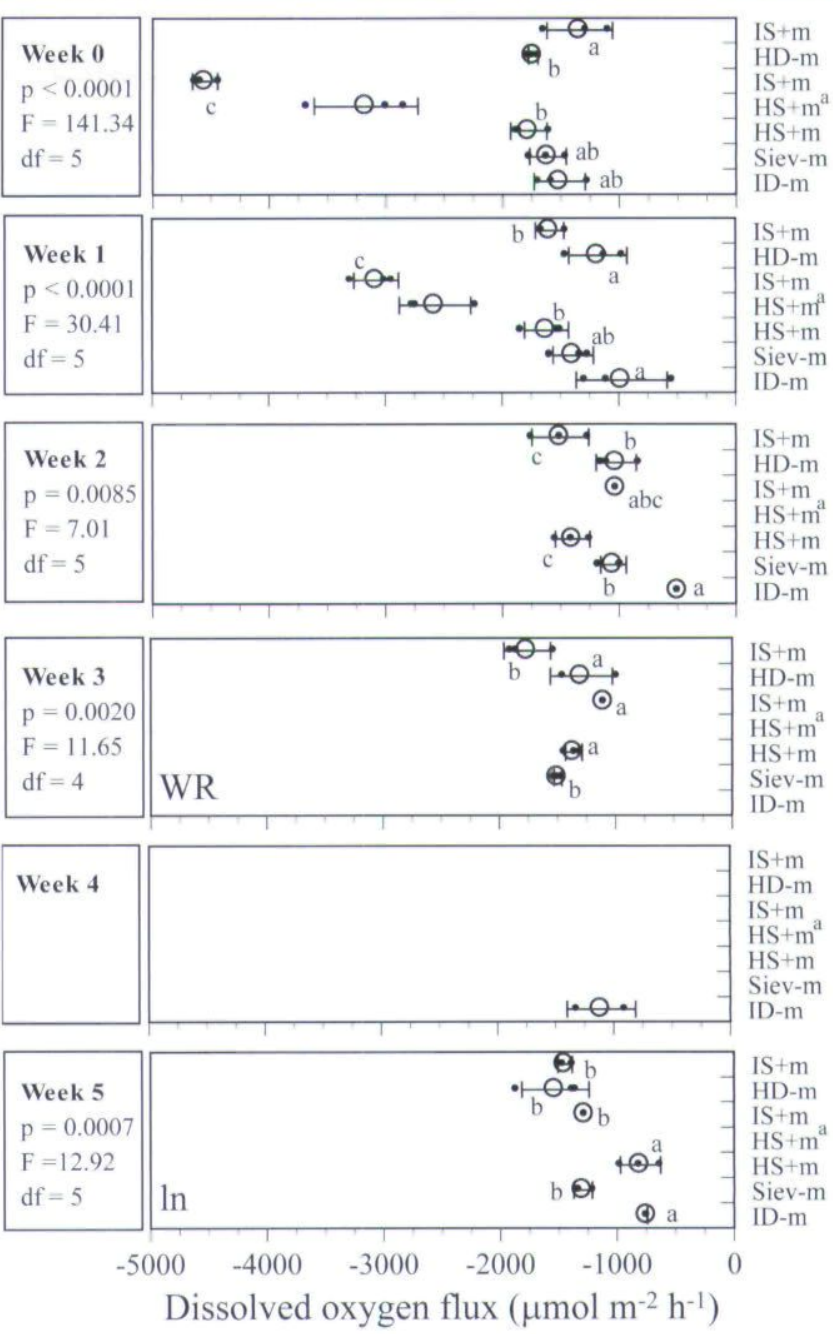

Figure 2. Dissolved oxygen fluxes measured approximately weekly over a 5 -wk period. The large open circle represents the mean flux rate and the bar the standard deviation. The symbols and statistics are the same as in Figure 2. For sediment preparation treatments, see Table 2.

The week $0 \mathrm{~N}_{2}-\mathrm{N}$ gas fluxes from the remixed treatment $\mathrm{HS}+\mathrm{m}$ averaged $\sim 300 \mu \mathrm{mol} \mathrm{m} \mathrm{m}^{-2} \mathrm{~h}^{-1}$ (Figure 4 ). Then week 1 rates of $\mathrm{N}_{2}-\mathrm{N}$ production ranged from about 50 to $200 \mu \mathrm{mol}$ $\mathrm{m}^{-2} \mathrm{~h}^{-1}$ in all treatments and were highest in treatments with macroinfauna (IS $+\mathrm{m}, \mathrm{HS}+\mathrm{m}^{\mathrm{a}}$; Figure 4$)$. On the basis of only one core, treatment IS $+\mathrm{m}$ had very high $\mathrm{N}_{2}-\mathrm{N}$ fluxes in week 5 .

Silicate fluxes were low across all treatments over the entire measurement period from weeks 0 to 5 (Figure 5) and were not significantly different between treatments, with the exception of silicate fluxes between treatments in weeks 1,2 , and 5. Silicate fluxes ranged from a slight uptake of about $-70 \mu \mathrm{mol} \mathrm{m}^{-2} \mathrm{~h}^{-1}$ in treatments IS $+\mathrm{m}, \mathrm{HS}+\mathrm{m}$, and Siev $-\mathrm{m}$ in week 0 and treatments IS $+m$ and $\mathrm{HD}-\mathrm{m}$ in week 1 to an efflux of about $150 \mu \mathrm{mol} \mathrm{m} \mathrm{m}^{-2} \mathrm{~h}^{-1}$ in all other treatments. Variability in silicate fluxes between treatments was slightly larger in weeks 0 and 1 .

Overall, for the biogeochemical fluxes, the treatments were 


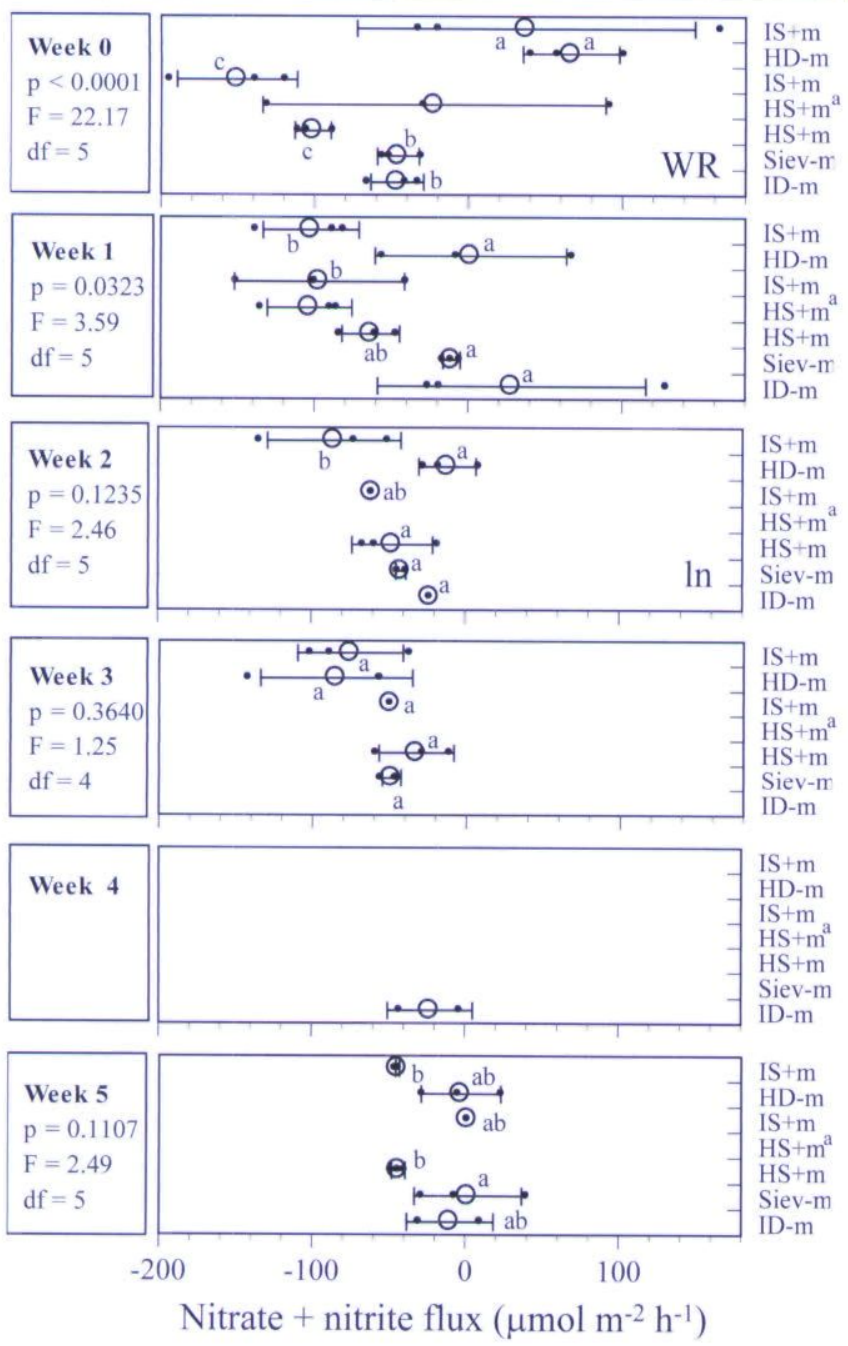

Figure 3. Nitrate + nitrite fluxes measured approximately weekly over a 5-wk period. The large open circle represents the mean flux rate and the bar the standard deviation. The symbols and statistics are the same as in Figure 2. For sediment preparation treatments, see Table 2.

significantly different as determined by ANOVA and least squares means comparisons, and the differences between treatments decreased with time. Fluxes became similar between treatments for nitrate + nitrite (Figure 3), $\mathrm{N}_{2}-\mathrm{N}$ (Figure 4), and silicate (Figure 5) after about week 2. Moreover, the $\mathrm{F}$ values decreased from 65 to 9 (Figure 1), 141 to 13 (Figure 2), and 22 to 2 (Figure 3 ) from week 0 to week 5 for ammonium, dissolved oxygen, and nitrate + nitrite fluxes, respectively, also indicating that the differences between treatments became smaller over time.

\section{Flux Changes of Weeks 0, 1, 2, and 3 Compared} with Week 5

The weekly flux rates were compared with week 5 (Figure 7) because at that time sediment fluxes had generally stabilized. For ammonium, we found the largest flux differences between weeks 0 and 5 and between weeks 1 and 5 , in par-

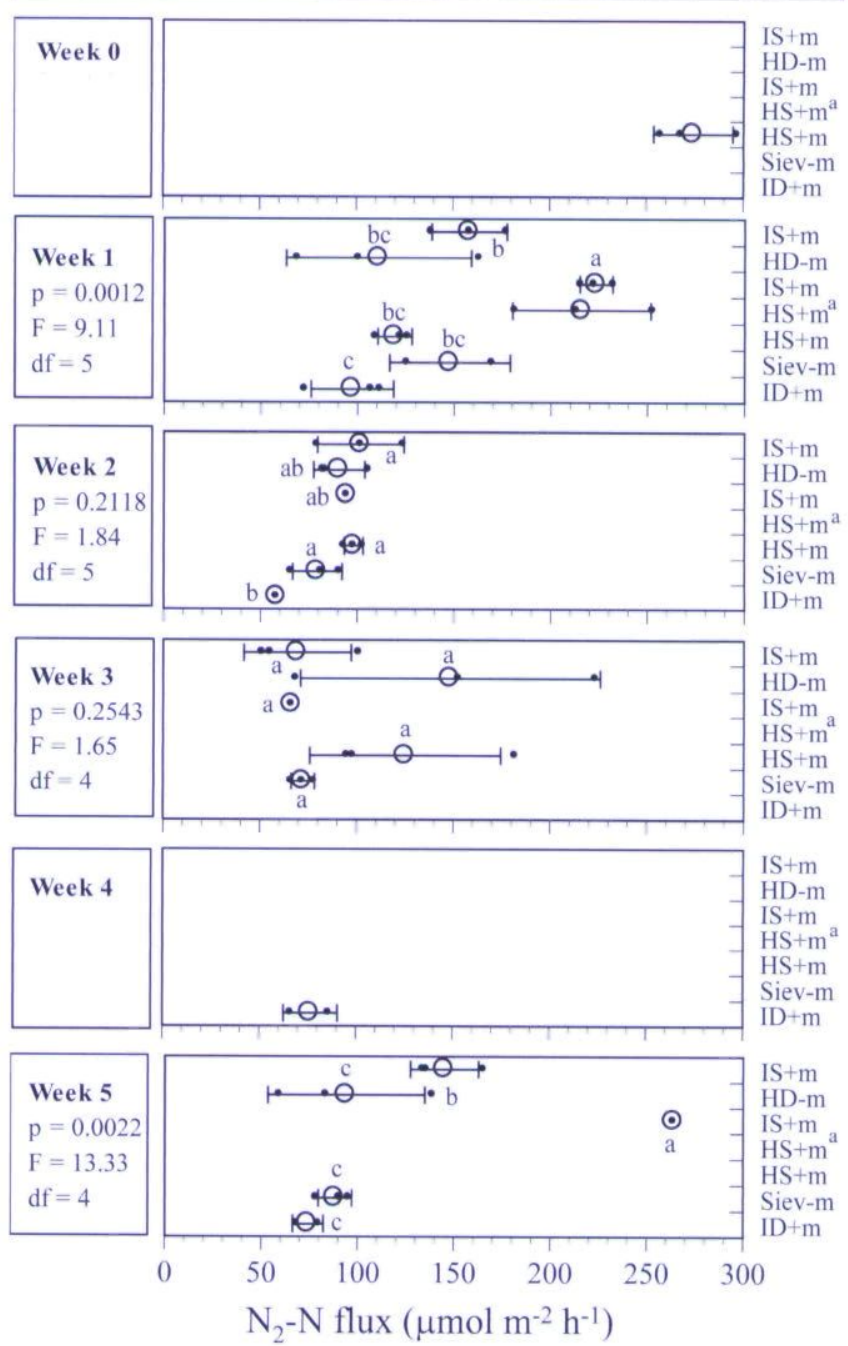

Figure 4. Nitrogen gas $\left(\mathrm{N}_{2}-\mathrm{N}\right)$ fluxes measured approximately weekly over a 5 -wk period. The symbols and statistics are the same as in Figure 2. Note that no $\mathrm{N}_{2}-\mathrm{N}$ gas measurements were made during week 0 , except for remixed treatment $\mathrm{HS}+\mathrm{m}^{a}$. For sediment preparation treatments, see Table 2.

ticular in $\mathrm{HS}+\mathrm{m}$ and IS $+\mathrm{m}$. The flux differences significantly decreased over time. In addition, the fluxes changed similarly for all treatments in weeks 2 to 5 and weeks 3 to 5 , respectively.

For dissolved oxygen, we found the largest flux differences between weeks 0 and 5 and between weeks 1 and 5 , in particular in $\mathrm{HD}+\mathrm{m}, \mathrm{HS}+\mathrm{m}$, and $\mathrm{IS}+\mathrm{m}$. The flux differences significantly decreased over time. In addition, the fluxes changed similarly for all treatments in weeks 2 to 5 and weeks 3 to 5 , respectively.

\section{Flux Changes from Week to Week}

In our comparison of all treatments together from week to week, ammonium and dissolved oxygen fluxes changed significantly from week 0 to 1 , week 1 to 2 , week 2 to 3 (Table 


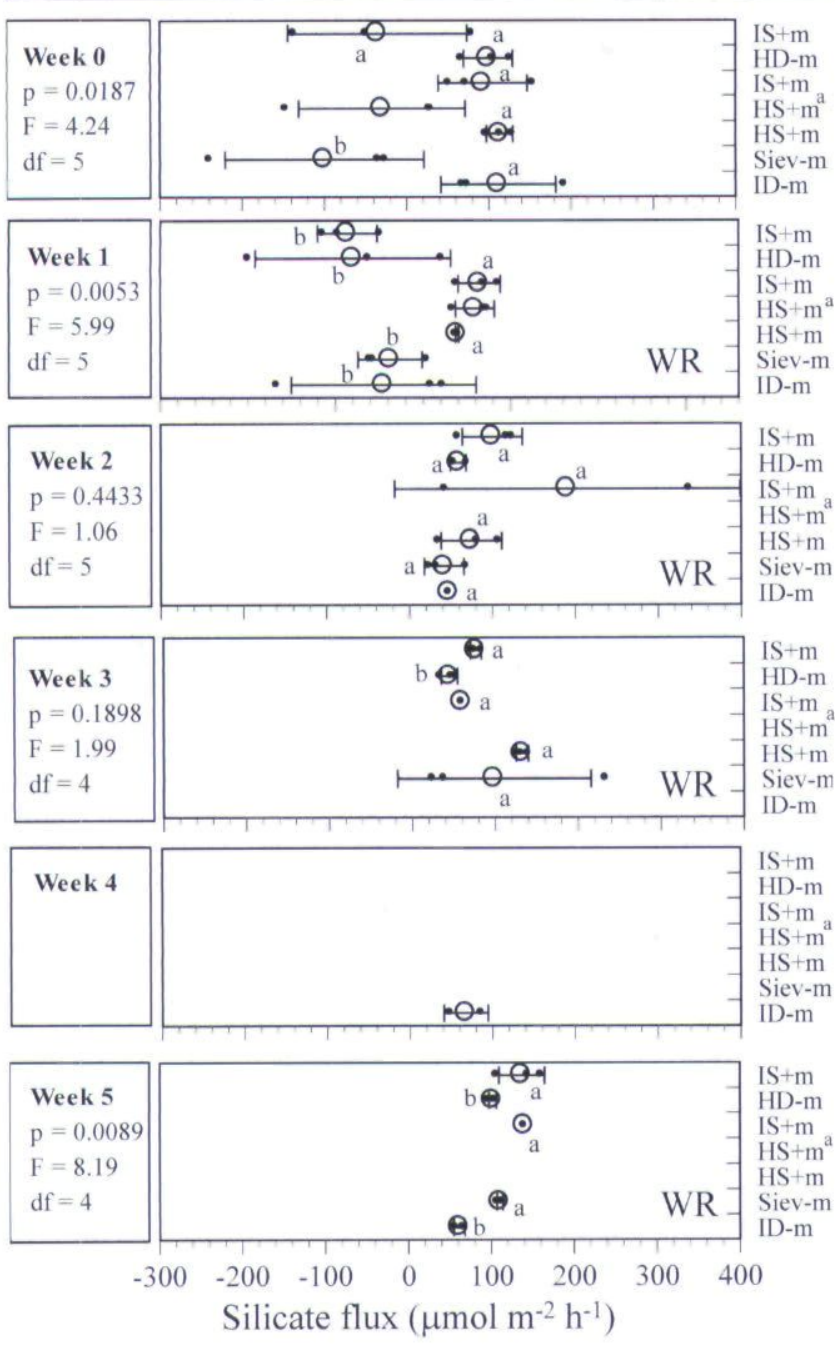

Figure 5. Silicate fluxes measured approximately weekly over a 5-wk period. The large open circle represents the mean flux rate and the bar the standard deviation. The symbols and statistics are the same as in Figure 2. For sediment preparation treatments, see Table 2.

3). However, ammonium and dissolved oxygen fluxes did not change significantly from week 3 to 5 (Table 4 ).

Thus, sediment preparation techniques significantly affected nutrient and gas fluxes, with some large temporal changes in gas and solute fluxes over time. Changes occurred until about week 2 or 3 , when fluxes became similar and lower
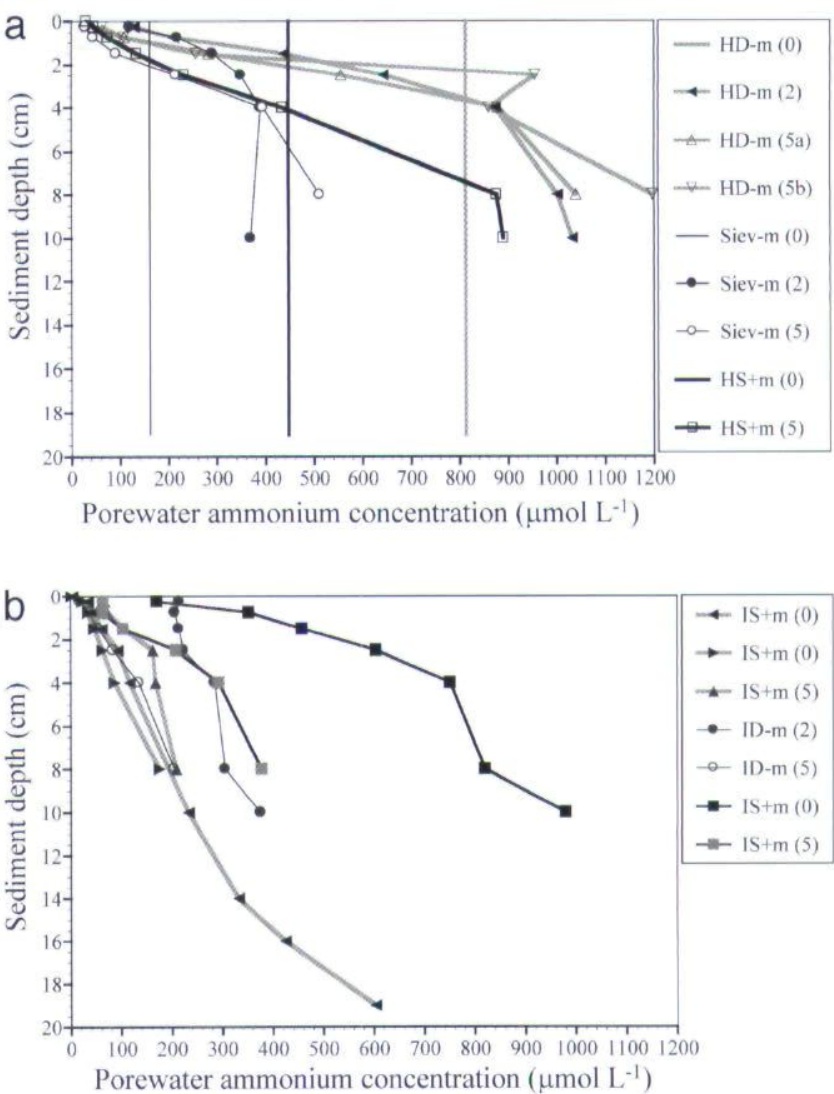

Figure 6. Ammonium porewater profiles on week 0 , week 2, and week 5 after application of the sediment treatment. For the sieved sediment $(\mathrm{Siev}-\mathrm{m})$, the homogenized surface sediment $(\mathrm{HS}+\mathrm{m})$, and the homogenized deep sediment $(\mathrm{HD}-\mathrm{m})$, the sediment was mixed and one sample was analyzed (line without points). For sediment preparation treatments, see Table 2 . Two cores were analyzed for treatment HD in week 5 (a, b).

among all treatments. However, nitrogen gas flux rates remained variable and silicate fluxes fairly high at the end.

The homogenized treatments and the treatments with macroinfauna had high initial fluxes and changed the most over time. These fluxes decreased over the 5 -week period. Flux changes became smaller over time in the homogenized treatment and in the intact sediment with macroinfauna; fluxes changed similarly for all sediment preparation techniques after about 2 to 3 weeks. After $\sim 2$ weeks, even severely manipulated sediments, such as our homogenized treatments,

Table 3. Statistical differences in dissolved oxygen and ammonium flux rates from week to week as determined by a repeated measures analysis of variance testing for the interaction of the treatment $x$ time effect. For both variables, we found significant trends over time that were not the same for all treatments. Probability is indicated as nonsignificant $(\mathrm{p}>0.05)$, and significant $(\mathrm{p}<0.05, \mathrm{p}<0.01$, and $\mathrm{p}<0.001$ ). Significant values are indicated in bold print.

\begin{tabular}{|c|c|c|c|c|}
\hline \multirow[b]{2}{*}{ Treatment } & \multicolumn{2}{|c|}{ Dissolved Oxygen } & \multicolumn{2}{|c|}{ Ammonium } \\
\hline & $p$ Value & $\mathrm{F}$ value for treatment & $p$ Value & $\mathrm{F}$ value for treatment \\
\hline Week 0 to week 1 & 0.0012 & 12.75 & $<0.0001$ & 96.22 \\
\hline Week 1 to week 2 & 0.0003 & 19.26 & 0.0059 & 7.89 \\
\hline Week 2 to week 3 & 0.0074 & 7.33 & 0.0386 & 4.09 \\
\hline Week 3 to week 5 & 0.1140 & 2.56 & 0.0588 & 3.45 \\
\hline
\end{tabular}



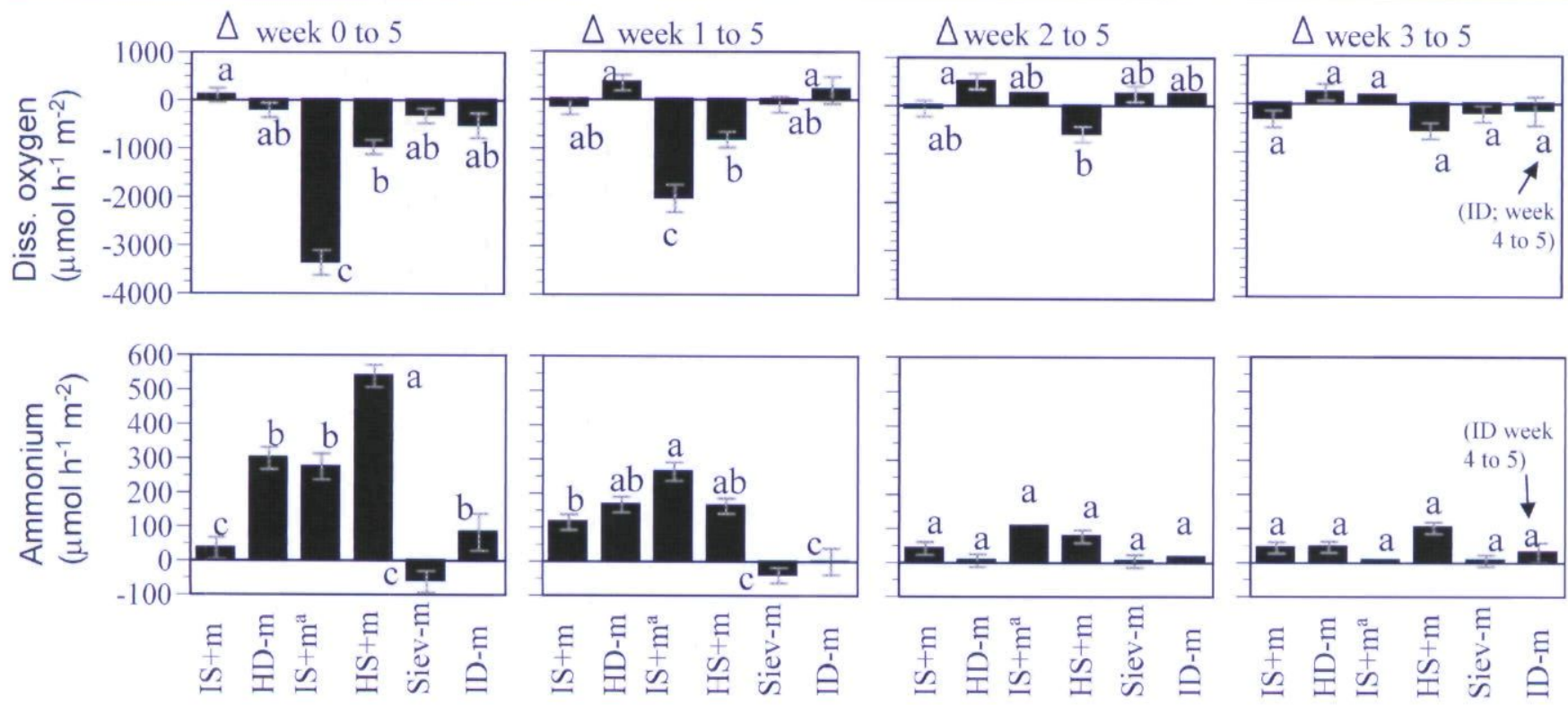

\begin{tabular}{|c|c|c|c|c|c|c|c|}
\hline Contrast & source & $\begin{array}{l}\text { F-value } \\
\text { Ammonium }\end{array}$ & $\begin{array}{l}\text { p-value } \\
\text { Ammonium }\end{array}$ & $\begin{array}{l}\text { mean flux } \\
\text { difference } \\
\text { Ammonium }\end{array}$ & $\begin{array}{l}\text { F-value } \\
\text { Diss. Oxygen }\end{array}$ & $\begin{array}{l}\text { p-value } \\
\text { Diss. Oxygen }\end{array}$ & $\begin{array}{l}\text { mean flux } \\
\text { difference } \\
\text { Diss. Oxygen }\end{array}$ \\
\hline $0-5$ & $\begin{array}{l}\text { mean } \\
\text { treatments }\end{array}$ & $\begin{array}{l}146.31 \\
44.75\end{array}$ & $\begin{array}{l}<0.0001 \\
<0.0001\end{array}$ & 190.45 & $\begin{array}{l}159.48 \\
30.68\end{array}$ & $\begin{array}{l}<0.0001 \\
<0.0001\end{array}$ & -916.68 \\
\hline $1-5$ & $\begin{array}{l}\text { mean } \\
\text { treatments }\end{array}$ & $\begin{array}{l}99.14 \\
14.12\end{array}$ & $\begin{array}{l}<0.0001 \\
0.0005\end{array}$ & 116.26 & $\begin{array}{l}29.67 \\
10.47 \\
\end{array}$ & $\begin{array}{l}0.0004 \\
0.0015\end{array}$ & -484.45 \\
\hline $2-5$ & $\begin{array}{l}\text { mean } \\
\text { treatments }\end{array}$ & $\begin{array}{c}2.68 \\
15.68\end{array}$ & $\begin{array}{l}0.1039 \\
\mathbf{0 . 0 0 4 2}\end{array}$ & 41.98 & $\begin{array}{r}1.3 \\
5.28\end{array}$ & $\begin{array}{l}0.2879 \\
\mathbf{0 . 0 1 7 4}\end{array}$ & 97.66 \\
\hline $3-5$ & $\begin{array}{l}\text { mean } \\
\text { treatments }\end{array}$ & $\begin{array}{l}18.17 \\
3.95\end{array}$ & $\begin{array}{l}0.0021 \\
0.0358\end{array}$ & 36.01 & $\begin{array}{l}4.32 \\
2.7\end{array}$ & $\begin{array}{l}0.0675 \\
0.0929\end{array}$ & -172.43 \\
\hline
\end{tabular}

Figure 7. Comparison of within-core treatment effects for dissolved oxygen and ammonium. The $\mathrm{F}$ and $p$ values were obtained from a one-way analysis of variance. The mean flux difference is expressed in $\mu \mathrm{mol} \mathrm{h}^{-1} \mathrm{~m}^{-2} ; n=3$ for all treatments and weeks except: $n=1$ for IS $+\mathrm{M}$ after weeks 2 (different core used), 3 , and $5 ; n=1$ for ID for week 2 ; and $n=2$ for treatment ID for weeks 4 and 5 . No week 3 data are available for ID; ID was run in week 4 instead of week 3 . Letters of within-week differences indicate statistical differences at the $p<0.05$ level. Other probabilities are indicated as nonsignificant $(p>0.05)$ and significant $(p<0.05, p<0.01$, and $p<0.001)$. For sediment preparation treatments, see Table 2 .

Table 4. Mean difference of dissolved oxygen and ammonium between weeks 3 and 5 and the p value for the test of the null hypothesis that the mean difference is zero between weeks 3 and 5. Probability is indicated as nonsignificant $(\mathrm{p}>0.05)$ and significant $(\mathrm{p}<0.05, \mathrm{p}<0.01$, and $\mathrm{p}<$ 0.001 ). Probabilities of $0.1>\mathrm{p}>0.05$ are nonsignificant but are indicative of a trend. Significant values are indicated in bold print.

\begin{tabular}{lccccc}
\hline \hline & \multicolumn{2}{c}{ Dissolved Oxygen } & & \multicolumn{2}{c}{ Ammonium } \\
\cline { 2 - 3 } \cline { 5 - 6 } Treatment & $\begin{array}{c}\text { Difference } \\
\left(\mu \mathrm{mol} \mathrm{m}^{-2} \mathrm{~h}^{-1}\right)\end{array}$ & $p$ Value & & $\begin{array}{c}\text { Difference } \\
\left(\mu \mathrm{mol} \mathrm{m}^{-2} \mathrm{~h}^{-1}\right)\end{array}$ & $p$ Value \\
\hline $\mathrm{IS}-\mathrm{m}$ & -315.75 & 0.0975 & & 43.81 & $\mathbf{0 . 0 3 2 8}$ \\
$\mathrm{HD}+\mathrm{m}$ & 232.54 & 0.2064 & & 45.45 & $\mathbf{0 . 0 2 8 1}$ \\
$\mathrm{IS}+\mathrm{m}$ & 174.15 & 0.5705 & & 5.9 & 0.8489 \\
$\mathrm{HS}+\mathrm{m}$ & -558.52 & $\mathbf{0 . 0 0 9 7}$ & & 102.32 & $\mathbf{0 . 0 0 0 2}$ \\
Siev $-\mathrm{m}$ & -203.77 & 0.2632 & & 5.98 & 0.7388 \\
ID $-\mathrm{m}^{*}$ & -363.26 & 0.1164 & & 12.6 & 0.5684 \\
\hline
\end{tabular}

eventually equilibrated to low and constant flux rates for all nutrients and gas species. A deep sediment core, chosen to mimic dredged sediment, initially exhibited enhanced fluxes that also decreased over time. Unlike the other treatments, sieved muddy sediment exhibited low fluxes over the entire 5 -week period, likely a result of "washing" ammonium out of the sediment during sieving. Overall, the variability in most treatments was high initially, and with time, the variability within treatments and between treatments decreased. By the end of the experiment, the fluxes tended to converge on an average value.

\section{DISCUSSION}

It has been assumed in previous studies, but not tested, that manipulated sediments equilibrate before any treatment additions, although the time period before treatment addi- 
tions has been extremely variable (Table 1 ). Sometimes oxygen or carbon dioxide fluxes have been used as an indicator for sediment equilibration in which treatments were added after oxygen or carbon dioxide fluxes had stabilized (HANSEN and BLACKBURN, 1991). With different types of sediment, it took between 7 and 14 days for gas fluxes to stabilize (HANSen and Blackburn, 1991; Pelegrí, Nielsen, and BlackBURN, 1994; RYSGAARD et al., 1994). In our comparative study with differently manipulated muddy sediment, it took between 0 and 3 weeks for oxygen fluxes to stabilize. Moreover, at the same time, gas and nutrient fluxes stabilized to low rates and fluxes did not change much after 2 weeks.

Sieving of sediments with a $0.5-\mathrm{mm}$ mesh, a technique commonly used to remove macroinfauna (e.g., CAFFrEY et al., 1993; Pelegrí, Nielsen, and BlackBurn, 1994; RysgaARD et al., 1994), removes particles larger than the sieve size. Sieving can also break apart aggregates, increase pore spaces, increase the water content of sediment, and disturb porewater gradients. In addition, macrofauna can be damaged or killed in the sieving process, adding organic matter to the sediment. Initial sieved ammonium fluxes were $\sim 20 \mu \mathrm{mol}$ $\mathrm{m}^{-2} \mathrm{~h}^{-1}$, significantly lower than the other two homogenized sediment treatments, with differences between treatments reflected in the initial porewater concentrations. Low ammonium concentrations and fluxes might result from handling losses and ammonium desorption. Contrary to our expectation, initial ammonium effluxes were very low from the deep sediment section (ID-m treatment).

Sediment homogenization or other sediment defaunation could disrupt natural porewater gradients; alter microbial populations in the sediment; redistribute, bury, or break up labile particulate organic matter; and redistribute iron sulfide minerals to the surface where they would be oxidized. Sediment homogenization has been shown to dramatically affect solute reaction rates (i.e., slurries; REEBURGH, 1983) and sulfate reduction rates measured from porewaters (LIEBERT, 1997).

Because macrofauna can profoundly affect geochemical fluxes, they are often removed from experiments to simplify experimental treatments and reduce variability. Sediment flux core incubations have been initiated over a broad range of times after the removal of the invertebrates (Table 1). We observed high initial uptake rates of dissolved oxygen and high initial ammonium effluxes in the cores with macroinfauna, and it is well known that macroinfauna can alter biogeochemical fluxes through bioirrigation and bioturbation (Aller, 1980, 1982; Forster et al., 1995; KrISTENSEN and Blackburn, 1987; Pelegrí, Nielsen, and Blackburn, 1994). However, fluxes decreased over time, possibly because the activity of the infauna decreased or because organic matter was not added to the cores during the experiment to "feed" the fauna and the sediment. It has, for example, been demonstrated that the addition of particulate organic matter increases nutrient flux rates and alters nutrient transformations (e.g., CAFFrEY et al., 1993; ENOKKSON, 1993; NEWELL, CORNWELL, and OWENS, 2002).

Many of our sediment treatments represented a high sediment disturbance. In nature, the use of fishing gear for clamming, boat moorings, boat propellers, or dredging activities can severely scar and disturb sediments (DAwEs et al., 1997; RUFFIN, 1998; WALKER et al., 1989), affect ammonium concentrations (FALCAO et al., 2003), and alter sediment biogeochemical fluxes. Similarly, the nutrient and contaminant dynamics in coastal ecosystems could be altered through sediment resuspension (KIM et al., 2004, 2006; PoRTER et al., unpublished data). Large-scale removal or mixing of sediment by dredging activities (Dawes et al., 1997) can exchange porewater with the water column and alter benthic fluxes. The removal of the top sediment layer will also remove the labile organic matter and the aerobic microbial populations such as the nitrifiers.

We were surprised to find only slightly enhanced initial effluxes of ammonium from the intact deep cores. The cores had been collected 2 days before the initial flux experiments and had been re-aerated before the start of the flux experiment, and it appeared that the initial oxygenation of the sediment and establishment of microbial population might have been relatively fast. Subsequent incubations of Chesapeake mainstem sediment sections from $1 \mathrm{~m}$ beneath the surface (much deeper than those used in this study) and incubated less than 2 days after collection, resulted in initial ammonium effluxes of more than $2000 \mu \mathrm{mol} \mathrm{L}{ }^{-1} \mathrm{~m}^{-2}$ (CORNWELL and Owens, 1999; Cornwell, Owens, and Pride, 2000).

The artificially large enhancement of initial ammonium effluxes can mask ammonium effluxes from the treatment of interest and could be misleading. In general, high ammonium effluxes could obscure the experimental effects of mesocosm experiments (BREITBURG et al., 1999) and possibly affect water column primary production (COWAN and BoYNTON, 1996). In addition, the initial conditions of "artificial" ecosystems can affect experimental responses (GIDDINGS and EDDlemon, 1979; Pilson, Oviatt, and Nixon, 1978). Ammonium effluxes and low oxygen conditions can act as adverse chemical cues for larval settlement and recruitment (MARINELli and WoOdin, 2002, 2004; WoOdin, Marinelli, and LINDSAY, 1998). Sediment disturbance affects responses at the population and community level differently and at different time scales (RHOADS, MCCALL, and YINGST, 1978; ZAJAC and Whitlatch, 1982a, 1982b, 2003). Sediment disturbance and the degree of disturbance have also been found to affect recovery time of biota to sites (DERNIE et al., 2003; NEWELL, Seiderer, and Hitchcock, 1998; RhoAds, McCALL, and YINGST, 1978) with recovery times of $>200$ days (DERNIE et al., 2003).

Interestingly, we did not find any detectable SRP fluxes throughout the entire experiment. Initially, we had expected SRP to desorb from particles under anaerobic conditions and appear as a measurable flux rate. Subsequent incubations of deep sediment cores that had been removed and manipulated under anaerobic conditions until the very start of the flux experiments similarly showed low SRP effluxes (CORNWELL and OWENS, 1999). It is possible that the surface layer of sediment could rapidly re-oxidize, thereby quickly trapping any upward-moving porewater SRP as it is adsorbed in oxic sediments (KROM and BERNER, 1980). BRAY, BRICKER, and Troup (1973) also found iron oxidation effects of porewater SRP concentrations that removed inorganic phosphate from solution by precipitation as iron phosphate. Understanding 
the effects of sediment manipulations on SRP cycling requires further study.

In many land-based mesocosm facilities, such as the Marine Ecosystem Research Laboratory (e.g., Pilson, Oviatt, and Nixon, 1978), the Multiscale Experimental Ecosystem Research Center (e.g., Petersen, Chen, and Kemp, 1997; Porter, 1999), and the mesocosm facility in The Netherlands of PRINs et al. (1995), large quantities of sediment are required for the study of realistic ecosystem processes, and it is not always feasible to sieve the sediments. To reduce sediment reactivity and remove macroinfauna, azoic sediments have been used (PRINs et al., 1995), or natural sediments have been mixed with sand (Petersen, Chen, and Kemp, 1997; Petersen, Sanford, and Kemp, 1998) to keep the organic content small, which, however, has produced cementlike hardened sediments and resulted in alternating patches of coarse and fine sediment (Petersen, Chen, and Kemp, 1997; Petersen, SAnford, and Kemp, 1998).

One useful technique for large-scale sediment defaunation and "equilibration" for mesocosm experiments was illustrated in our treatment with $\mathrm{HD}-\mathrm{m}$ sediment. Natural sediments are collected, moved into a large dark tank, and rendered anaerobic for 3 to 4 days to trigger macroinfauna to come to the surface; then, the top $10 \mathrm{~cm}$ of sediments with macroinfauna are removed. Any macroinfauna that does not reach the sediment surface will be killed and decompose at depths that should not affect the sediment nutrient and gas flux rates into the water column of the system. These defaunated sediments in flux cores can then be equilibrated for a 2-week period in a water basin with filtered water. For experiments in enclosed mesocosms in which no flow-through water stream, such as in our holding tank, can be established, an overlying water column of about $20 \mathrm{~cm}$ depth should be added carefully to the tanks, and half of the water should be replaced daily for about 14 days to flush out any ammonium released from the sediments into the water. The sediments in the tanks must be kept in the dark at all times. After the equilibration period, a treatment of choice can be added to the sediments and the mesocosm experiments begun. This homogenized deep sediment treatment has subsequently been used for all our ecosystem experiments that included sediment (e.g., KIM et al., 2004; PorTER et al., 2004a, 2004b).

We tested a number of important and commonly used sediment manipulations and defaunation techniques but did not include sediment manipulation techniques such as freezing or irradiation. Freezing of sediments (BRUCKNER et al., 1995; SMITH and BRUMSICKLE, 1989) or sediment irradiation (GOLDE et al., 1994) does not cause the kind of major disturbance to porewaters, sulfides, and labile organic matter observed in the homogenized and sieved sediments (BRUCKNER et al., 1995). However, freezing or irradiation treatments can introduce further artifacts because of expansion of porewater spaces in frozen sediments and because of the killing of not only macroinfauna but also meiofauna and all microbial populations in the irradiated sediments. We chose natural sediments for our sediment manipulations because they included natural initial inoculations of microbial populations that, presumably, should lead to a faster re-establishment of natural microbial populations and gradients. Further comparative experiments should be done to compare the effect of freezing, irradiation, and the sediment preparation techniques described here on nutrient and gas fluxes over time.

\section{Conclusions and Recommendations for Sediment Preparation}

After about 2 weeks, different defaunation approaches yielded relatively constant nutrient and gas flux rates, presumably after the re-establishment of microbial communities and biogeochemical gradients. Additions of macroinvertebrates and subsequent reactions in defaunated sediments occurred on the surface portion of the sediments; thus, it is important to represent biogeochemical processes at the surface of the sediment adequately. High initial effluxes of ammonium from homogenized sediments must be a concern in experimental ecosystem studies because they could represent a temporal artifact. High initial fluxes might mask the treatment additions or could be misinterpreted as the effect of the treatment of interest. Sieved sediments displayed the lowest overall effluxes and changes in flux rates over time and are a good choice for defaunating sediments if only small amounts of sediments are needed. If large amounts of defaunated and equilibrated sediments are needed, natural surface sediments should be collected and the macrofauna driven to the surface by anoxia and removed. A 2-week sediment equilibration period in the experimental ecosystems accompanied by a daily partial flushing of the overlying water leads to a removal of the initial nutrients released from the sediments. Overall, sediment manipulations result in disruption of biogeochemical processes; a period of equilibration is required before pertinent biogeochemical processes can be studied.

\section{ACKNOWLEDGMENTS}

We are grateful to research statistician Dr. E. Perry for his statistical advice and for his help with the SAS programs for the various statistical analyses. We thank E. Kiss for performing the grain size analysis. Our research was supported by grant R $824850-01-0$ by the EPA STAR program as part of the Multiscale Experimental Ecosystem Research Center at the University of Maryland Center for Environmental Science. Contribution No. 2972 of the University of Maryland Center for Environmental Science.

\section{LITERATURE CITED}

AlLER, R.C., 1980. Relationships of tube-dwelling benthos with sediment and overlying water chemistry. In: TENORE, K.R., and Coull, B.C. (eds.), Marine Benthic Dynamics. Columbia City, South Carolina: University of South Carolina, Columbia Press, pp. 285-308

ALLER, R.C., 1982. The effects of macrobenthos on chemical properties of marine sediment and overlying water. In: McCALL, P.L., and Tevesz, M.J.S. (eds.), Animal-Sediment Relations. New York: Plenum Press, pp. 53-102.

Andersen, F.O. and Kristensen, E., 1988. The influence of macrofauna on estuarine benthic community metabolism: a microcosm study. Marine Biology, 99, 591-603.

Bray, J.T.; Bricker, O.P., and Troup, B.N., 1973. Phosphate in interstitial waters of anoxic sediments: oxidation effects during sampling procedure. Science, 180, 1362-1364. 
Breitburg, D.L.; Sanders, J.G.; Gilmour, C.C.; Hatfield, C.A.; Osman, R.W.; Riedel, G.F.; Seitzinger, S.B., and Sellner, K.G., 1999. Variability in responses to nutrients and trace elements, and transmission of stressor effects through an estuarine food web. Limnology and Oceanography, 44, 837-863.

BRUCKNER, A.; KAMPICHLER, C.; Wright, J.; BAUER, R., and KANDELER, E., 1995. A method of preparing mesocosms for assessing complex biotic processes in soils. Biology and Fertility of Soils, 19, $257-262$

CafFrey, J.M.; Sloth, N.P.; Kaspar, H.F., and Blackburn, T.H., 1993. Effect of organic loading on nitrification and denitrification in a marine sediment microcosm. FEMS Microbiology, Ecology, 12, 159-167.

Cornwell, J.C. and Owens, M.S., 1999. The Nutrient Chemistry of Sediment Dredging: Sediment Nutrient Inventories and Fluxes. Final report to Maryland Environmental Service Under Contract to the Maryland Port Administration. UMCES Report TS-187-99. Cambridge, Maryland: University of Maryland Center for Environmental Science.

CoRnwell, J.C.; Owens, M.S., and PRIDE, L., 2000. Nitrogen and Phosphorus Releases during Dredging: Assessing Potential Phosphorus Releases and Refinement of Ammonium Release Estimates. Final report to Maryland Environmental Service under contract to the Maryland Port Authority. UMCES Report TS-23000. Cambridge, Maryland: University of Maryland Center for Environmental Science.

Cowan, J.L. and Boynton, W.R., 1996. Sediment-water oxygen and nutrient exchanges along the longitudinal axis of Chesapeake Bay: seasonal patterns, controlling factors, and ecological significance. Estuaries, 19, 562-580.

Dawes, C.J.; Andorfer, J.; Rose, C.; UnANowski, C., and EhrinGER, N., 1997. Regrowth of the seagrass Thalassia testudinum into propeller scars. Aquatic Botany, 59, 139-155.

Dernie, K.M.; Kaiser, M.J.; Richardson, E.A., and WarWick, R.M., 2003. Recovery of soft sediment communities and habitats following physical disturbance. Journal of Experimental Marine Biology and Ecology, 285, 415-434.

Doering, P.H.; Kelly, J.R.; Oviatt, C.A., and Sowers, T., 1987. Effect of the hard clam Mercenaria mercenaria on benthic fluxes of inorganic nutrients and gases. Marine Biology, 94, 377-383.

Doering, P.H.; Oviatt, C.A., and Kelley, J.F., 1986. The effects of the filter feeding clam Mercenaria mercenaria on carbon cycling in experimental mesocosms. Journal of Marine Research, 44, 839861.

ENOKSSON, V., 1993. Nutrient recycling by coastal sediments: effects of added algal material. Marine Ecology Progress Series, 92, 245254 .

Escaravage, V.; Prins, T.C.; Smaal, A.C., and Peeters, J.C.H., 1996. The response of phytoplankton communities to phosphorus input reduction in mesocosm experiments. Journal of Experimental Marine Biology and Ecology, 198, 55-79.

Falcao, M.; Gaspar, M.B.; Caetano, M.; Santos, M.N., and Vale, C., 2003. Short-term environmental impact of clam dredging in coastal waters (south of Portugal): chemical disturbance and subsequent recovery of seabed. Marine Environmental Research, 56, 649-664.

Fletcher, R.; Reynoldson, T.B., and TAYlor, W.D., 2001. Maintenance of intact sediment box cores as laboratory mesocosms. En vironmental Pollution, 115, 183-189.

Forster, S.; GraF, G.; KitlaR, J., and Powilleit, M., 1995. Effects of bioturbation in oxic and hypoxic conditions-a microcosm experiment with a North-Sea sediment community. Marine Ecology Progress Series, 116, 153-161.

Giblin, A.E.; Hopkinson, C.S., and Tucker, J., 1997. Benthic metabolism and nutrient cycling in Boston Harbor, Massachusetts. Estuaries, 20, 346-364.

Giddings, J.M. and EdDlemon, G.K., 1979. Some ecological and experimental properties of complex aquatic microcosms. International Journal of Environmental Studies, 13, 119-123.

Golde, H.M.; Crosby, M.B.; Lovell, C.R., and Stancy, S.E., 1994. Reduction of marine sediment oxygen uptake: pre-treatment for the determination of infaunal respiration rates. Marine Ecology Progress Series, 111, 203-207.

Hansen, K.; King, G.M., and KRISTENSEN, E., 1996. Impact of the soft-shell clam Mya arenaria on sulfate reduction in an intertidal sediment. Aquatic Microbial Ecology, 10, 181-194.

Hansen, L.S. and BlackBURN, T.H., 1991. Aerobic and anaerobic mineralization of organic material in marine sediment microcosms. Marine Ecology Progress Series, 75, 283-291.

Johnson, R.A. and Wichern, D.W., 1982. Applied Multivariate Analysis, Chapter 6. Englewood Cliffs, New Jersey: Prentice Hall.

JøRGENSEN, B.B., 1980. Seasonal oxygen depletion in the bottom waters of a Danish fjord and its effects on the benthic community. Oikos, 34, 68-76.

Kana, T.M.; Darkangelo, C.; Hunt, M.D.; Oldham, J.B.; BenNETT, G.E., and CoRnwell, J.C., 1994. Membrane inlet mass spectrometer for rapid high-precision determination of $\mathrm{N}_{2}, \mathrm{O}_{2}$ and $\mathrm{Ar}$ in environmental water samples. Analytical Chemistry, 66, $4166-417$.

Kana, T.M.; Sullivan, M.B.; Cornwell, J.C., and Groszkowski, K.M., 1998. Denitrification in estuarine sediments determined by membrane inlet mass spectrometry. Limnology and Oceanography, $43,334-339$.

Kim, E.-H.; Mason, R.P.; Porter, E.T., and Soulen, H.L., 2004. The effect of resuspension on the fate of total mercury and methyl mercury in a shallow estuarine ecosystem: a mesocosm study. $\mathrm{Ma}$ rine Chemistry, 86, 121-137.

Kim, E.-H.; Mason, R.P.; Porter, E.T., and Soulen, H.L., 2006. The impact of resuspension on sediment mercury dynamics, and methylmercury production and fate: A mesocosm study. Marine Chemistry, 102, 300-315.

KRISTENSEN, E. and BlackBURN, T.H., 1987. The fate of organic carbon and nitrogen in experimental marine sediment systems: influence of bioturbation and anoxia. Journal of Marine Research, $45,231-257$.

Kristensen, E. and Hansen, K., 1995. Decay of plant detritus in organic-poor sediment: production rates and stochiometry of dissolved C and N compounds. Journal of Marine Research, 53, 675702.

Krom, M.D. and Berner, R.A., 1980. Adsorption of phosphate in anoxic marine sediments. Limnology and Oceanography, 25, 797806.

Liebert, A., 1997. Metabolism and Nutrient Cycling in Experiments Marsh Sediments. College Park, Maryland: University of Maryland, Master's thesis.

Marinelli, R.L. and Woodin, S.A., 2002. Experimental evidence for linkages between infaunal recruitment, disturbance, and sediment surface chemistry. Limnology and Oceanography, 47, 221229.

MARINELLI, R.L. and Woodin, S.A., 2004. Disturbance and recruitment: a test of solute and substrate specificity using Mercenaria mercenaria and Capitella sp. Marine Ecology Progress Series, 269, 209-221.

MARTIN, W.R. and BANTA, G.T., 1992. The measurement of sediment irrigation rates: a comparison of the $\mathrm{BR}^{-}$tracer and ${ }^{222} \mathrm{RN} /$ ${ }^{226} \mathrm{RA}$ disequilibrium techniques. Journal of Marine Research, 50, $125-154$.

Meyers, M.B.; Fossing, H., and Powell, E.N., 1987. Microdistributuion of interstitial meiofauna, oxygen and sulfide gradients, and the tubes of macro-infauna. Marine Ecology Progress Series, $35,223-241$

Newell, R.C.; Seiderer, L.J., and HitchCock, D.R., 1998. The impact of dredging works in coastal waters: a review of the sensitivity to disturbance and subsequent recovery of biological resources on the sea bed. Oceanography and Marine Biology. An Annual Review, 36, 127-178.

Newell, R.I.E.; CoRnwell, J.C., and Owens, M., 2002. Influence of simulated bivalve biodeposition and microphytobenthos on sediment nitrogen dynamics. Limnology and Oceanography, 47, 13671379 .

Nielsen, K.; Nielsen, L.P., and RAsmussen, P., 1995. Estuarine nitrogen-retention independently estimated by the denitrification 
rate and mass-balance methods-a study of Norsminde Fjord, Denmark. Marine Ecology Progress Series, 119, 275-283.

Oviatt, C.; Doering, P.; Nowicki, B.; Reed, L.; Cole, J., and FrITHSEN, J., 1995. An ecosystem level experiment on nutrient limitation in temperate coastal marine environments. Marine Ecology Progress Series, 116, 171-179.

Parsons, T.R.; Maita, Y., and Lalli, C.M., 1984. A Manual of Chemical and Biological Methods for Seawater Analysis. Oxford, UK: Pergamon Press.

Pelegrí, S.P.; Nielsen, L.P., and Blackburn, T.H., 1994. Denitrification in estuarine sediment stimulated by the irrigation activity of the amphipod Corophium volutator. Marine Ecology Progress Series, 105, 285-290.

Petersen, J.E.; Chen, C.-C., and KemP, W.M., 1997. Scaling aquatic primary productivity: experiments under nutrient- and lightlimited conditions. Ecology, 78, 2326-2338.

Petersen, J.E.; SAnford, L.P., and KemP, W.M., 1998. Coastal plankton responses to turbulent mixing in experimental ecosystems. Marine Ecology Progress Series, 171, 23-41.

Pietros, J.M. and Rice, M.A., 2003. The impacts of aquacultured oysters, Crassostrea virginica (Gmelin, 1791) on water column nitrogen and sedimentation: results of a mesocosm study. Aquaculture, 220, 407-422.

Pilson, M.E.Q.; Oviatt, C.A., and Nixon, S.W., 1978. Annual nutrient cycles in a marine microcosm. In: GIESY, J.P., JR. (ed.), Microcosms in ecological research. Springfield, Virginia: U.S. Department of Energy, pp. 753-778.

PORTER, E.T., 1999. Physical and biological scaling in experimental ecosystem studies. College Park, Maryland: University of Maryland, Doctoral thesis, 343p.

Porter, E.T.; Cornwell, J.C.; SANFord, L.P., and Newell, R.I.E., 2004a. Effect of oysters Crassostrea virginica and bottom shear velocity on benthic-pelagic coupling and estuarine water quality. Marine Ecology Progress Series, 271, 61-75.

Porter, E.T.; SANFord, L.P.; Gust, G., and Porter, F.S., 2004b. Combined water column mixing and benthic boundary-layer flow in mesocosms: key for realistic benthic-pelagic coupling studies. Marine Ecology Progress Series, 271, 43-60.

Prins, T.C.; Escaravage, V.; Smaal, A.C., and Peeters, J.C.H., 1995. Nutrient cycling and phytoplankton dynamics in relation to mussel grazing in a mesocosm experiment. Ophelia, 41, 289-315.

REEBURGH, W.S., 1983. Rates of biogeochemical processes in anoxic sediments. Annual Review of Earth and Planetary Sciences, 11, 269-298.
Rhoads, D.C.; MCCALL, P.L., and YIngST, J.Y., 1978. Disturbance and production on estuarine seafloor. American Scientist, 66, 577586.

RUFFIN, K.K., 1998. The persistence of anthropogenic turbidity plumes in a shallow water estuary. Estuarine, Coastal and Shelf Science, 47, 579-592.

RysgaARD, S.; RisgaARd-Petersen, N.; Sloth, N.P.; Jensen, K., and NiELSEN, L.P., 1994. Oxygen regulation of nitrification and denitrification in sediments. Limnology and Oceanography, 39, 1643-1652.

Scheiner, S.M. and Gurevitch, J., 1993. Design and Analysis of Ecological Experiments. New York: Chapman and Hall.

Sloth, N.P.; Blackburn, H.; Hansen, L.S.; Risgaard-Petersen, N., and LOMSTEIN, B.A., 1995. Nitrogen cycling in sediments with different organic loading. Marine Ecology Progress Series, 116, 163-170.

Smith, C.R. and BrumsickLE, S.J., 1989. The effects of patch size and substrate isolation on colonization modes and rates in an intertidal sediment. Limnology and Oceanography, 34, 1263-1277.

Sundback, K.; Enoksson, V.; Granelí, W., and Pettersson, K., 1991. Influence of sublittoral microphytobenthos on the oxygen and nutrient flux between sediment and water: a laboratory continuous-flow study. Marine Ecology Progress Series, 74, 263-279.

Walker, D.I.; Lukatelich, R.J.; Bastyan, G., and MCCOMB, J., 1989. Effect of boat moorings on seagrass beds near Perth, Western Australia. Aquatic Botany, 36, 69-77.

WoOdin, S.A.; MARINELLI, R.L., and LindSAY, S.M., 1998. Processspecific cues for recruitment in sedimentary environments: geochemical signals? Journal of Marine Research, 56, 535-558.

ZAJAC, R.N. and Whitlatch, R.B., 1982a. Responses of estuarine infauna to disturbance. 1. Spatial and temporal variation of initial recolonization. Marine Ecology Progress Series, 10, 1-14.

ZAJAC, R.N. and WhitLatch, R.B., 1982b. Natural and disturbanceinduced demographic variation in an infaunal polychaete, $\mathrm{Neph}$ tys-Incisa. Marine Ecology Progress Series, 57, 89-102.

ZaJAC, R.N. and Whitlatch, R.B., 2003. Community and population-level responses to disturbance in a sandflat community. Journal of Experimental Marine Biology and Ecology, 294, 101-125.

Ziebis, W.; HUETTEL, M., and Forster, S., 1996. Impact of biogenic sediment topography on oxygen fluxes in permeable sediments. Marine Ecology Progress Series, 140, 227-237.

Zimmermann, C.; Price, M., and Montgomery, J., 1977. Operation, Methods, and Quality Control of Technicon AutoAnalyzer II Systems for Nutrient Determination in Seawater. Fort Pierce, Florida: Harbor Branch Foundation, Inc. 
Copyright of Journal of Coastal Research is the property of Alliance Communications Group and its content may not be copied or emailed to multiple sites or posted to a listserv without the copyright holder's express written permission. However, users may print, download, or email articles for individual use. 